\title{
Comparison Analysis of Added Value of Organic Rice and Inorganic Rice
}

\author{
Dwi Eva Nirmagustina, ${ }^{1, *}$, Sri Handayani ${ }^{2}$
}

\begin{abstract}
${ }^{I}$ Department of Food Technology, Politeknik Negeri Lampung, Bandar Lampung, Indonesia, ${ }^{2}$ Department of Economic and Business Politeknik Negeri Lampung, Bandar Lampung, Indonesia, *Corresponding author.Email: dwievan94@polinela.ac.id, sri.handayani84@ polinela.ac.id
\end{abstract}

\begin{abstract}
Domestic rice consumption increases every year. The demand for organic rice by community has increased as well. In this case, whether organic rice provides added value to farmer compared to inorganic rice, and whether organic rice varieties (Mentik susu and Sintanur) provides different added values as well. The research method used in this study was the observation method on farmer in South Lampung Regency and Pringsewu District. The analytical method used was method of Hayami's approach. The results showed that added value of inorganic rice (Ciherang) was 0.14. Mentik susu verieties higher added value than Sintanur varieties, 0.28 and 0.15 , respectively. The conclusion of this study is organic rice provides higher added value than inorganic rice and organik rice of Mentik susu varieties provides higher added value than organic rice of Sintanur varieties.
\end{abstract}

Keywords: added value, organic rice, Mentik susu and Sintanur

\section{INTRODUCTION}

Rice is the main staple food of Indonesian people besides corn, cassava, and sweet potato. The average staple food consumption in 2017 is $1.571,0.026,0.122$, and $0.070 \mathrm{~kg}$ /capita/week, respectively [1]. Production of rice at Indonesia in 2018 was 32.42 million tons. Most of the rice produced is obtained through agricultural intensification, one of which is the use of chemical fertilizers and pesticides in the cultivation process. According to INOFICE (Indonesia Organic Farming Certification) organic rice is rice whose cultivation process used organic treatment from water for irrigation, fertilizers, until pesticides.

At present, rice cultivation with organic methods is increasing interest of farmers because of several advantages of organic rice such as higher total dietary fiber and protein, lower fat and reducing sugars than inorganic rice [2]. Therefore organic rice is better used by people with Diabetes Mellitus type 2 as an energy source food without worrying about an increase in blood sugar levels [3]. Business of organic rice is different from inorganic rice because of several things such as used of seeds, the application of cultivation, the amount of production, and the price of products on the marketplace.

Performance of the organic rice supply chain is in a superior position. This means that organic rice farming has been running as expected [4]. In addition, organic rice farming showed more efficient than inorganic farming [5].The purpose of this research is 1) to know whether organic rice and inorganic rice have a different added value, 2) to know whether organic ricevarieties (Mentik susu and Sintanur) have a different added values as well,
3) to know whether cultivation of organic rice give benefit for farmer.

\section{METHODS}

This research was conducted at center of organic rice cultivation in Pringsewu District and South Lampung Regency. Primary data retrieval was carried out to farmer groupof Sri Lestari who planted Sintanur varieties and farmer group of Mitra Organik who planted Mentik susu varieties. The selection of research respondents is based on the consideration the largest area cultivation of organic rice. Activties are carried out during Maaay - July 2019. Survey methods and direct observations in the field are used in the collection of primary and secondary data. The method of data analysis uses added vaue analysis [6]. Calculation of added value analysis that used the Hayami method. The Hayami method is used to calculation of added value and is presented in Table 1.

Table 1 Calculation of Hayami added value analysis

\begin{tabular}{|l|l|l|}
\hline No & Output, input, and price & Value \\
\hline 1 & Output $\left(\mathrm{kg} \cdot \mathrm{d}^{-1}\right)$ & $(1)$ \\
\hline 2 & Raw material Input $\left(\mathrm{kg} \cdot \mathrm{d}^{-1}\right)$ & $(3)$ \\
\hline 3 & Workers/ Labor $\left(\mathrm{h} \cdot \mathrm{d}^{-1}\right)$ & $(4)=((1) /(2)$ \\
\hline 4 & Conversion Factor & $(5)=(3) /(2)$ \\
\hline 5 & Workers Coefficient $\left(\mathrm{h} \cdot \mathrm{kg}^{-1}\right)$ & $(6)$ \\
\hline 6 & Price of Product (IDR $\left.\cdot \mathrm{kg}^{-1}\right)$ & \\
\hline
\end{tabular}




\begin{tabular}{|l|l|l|}
\hline No & Output, input, and price & \multicolumn{1}{|c|}{ Value } \\
\hline 7 & Salary (IDR $\left.\cdot \mathrm{h}^{-1}\right)$ & $(7)$ \\
\hline & Revenue and Profit & \\
\hline 8 & Raw material Input (IDR $\left.\cdot \mathrm{kg}^{-1}\right)$ & $(8)$ \\
\hline 9 & Other Inputs (IDR $\left.\cdot \mathrm{kg}^{-1}\right)$ & $(9)$ \\
\hline 10 & Production (IDR $\left.\cdot \mathrm{kg}^{-1}\right)$ & $(10)=(4) \mathrm{x}(6)$ \\
\hline 11 & Added value (IDR $\left.\cdot \mathrm{kg}^{-1}\right)$ & $(11 \mathrm{a})=(10)-(8)-(9)$ \\
\hline 12 & Added value ratio AV (\%) & $\begin{array}{l}(11 \mathrm{~b})=(11 \mathrm{a}),(10) \mathrm{x} \\
100\end{array}$ \\
\hline 13 & Revenue of Workers (IDR $\left.\cdot \mathrm{kg}^{-1}\right)$ & $=(5)^{*}(7)$ \\
\hline 14 & Workers share of VA (\%) & $\begin{array}{l}(12 \mathrm{~b})=(12 \mathrm{a}) /(11 \mathrm{a}) \mathrm{x} \\
100\end{array}$ \\
\hline 15 & Profit (IDR $\left.\cdot \mathrm{kg}^{-1}\right)$ & $(13 \mathrm{a})=(11 \mathrm{a})-(12 \mathrm{a})$ \\
\hline 16 & Rate of Profit (\%) & $\begin{array}{l}(13 \mathrm{~b})=(13 \mathrm{a}) /(10) \mathrm{x} \\
100\end{array}$ \\
\hline
\end{tabular}

The criteria used to find out the added value:

1. If $\mathrm{AV}>0$, then it can be interpreted that the development of home industry provides added value.

2. If $\mathrm{NT} \leq 0$, then it can be interpreted that the development of home industry does not provide added value.

\section{RESULTS AND DISCUSSION}

Organic rice analyzed was Mentik susu varieties and Sintanur varieties. While inorganic rice analyzed was Ciherang varieties.

The results of added value analysis of organic rice in both of farmer groups (Sri Lestari and Mitra Organic) can be seen in Table 2.

Table 2 Results of added value calculation of organic rice and inorganic rice 1 cultivation period MT2 2018 (0.25 Hectares)

\begin{tabular}{|l|l|r|r|r|}
\hline No & \multirow{2}{*}{ Output, input, and price } & \multicolumn{2}{|c|}{ Varietas } & Cihe \\
\cline { 3 - 4 } & & Sintanur & $\begin{array}{l}\text { Mentik } \\
\text { rang }\end{array}$ & \\
\hline 1 & Output $\left(\mathrm{kg} \cdot \mathrm{d}^{-1}\right)$ & 1200 & 1100 & 1560 \\
\hline 2 & Raw material Input $\left(\mathrm{kg} \cdot \mathrm{d}^{-1}\right)$ & 1800 & 1600 & 2400 \\
\hline 3 & Workers/ Labor $\left(\mathrm{h} \cdot \mathrm{d}^{-1}\right)$ & 25 & 23 & 17 \\
\hline 4 & Conversion Factor & 0.67 & 0.69 & 0.65 \\
\hline 5 & Workers Coefficient $\left(\mathrm{h} \mathrm{kg}^{-1}\right)$ & 0.01 & 0.01 & 0.01 \\
\hline 6 & Price of Product (IDR $\left.\cdot \mathrm{kg}^{-1}\right)$ & 12000 & 15000 & 7500 \\
\hline 7 & Salary (IDR $\left.\cdot \mathrm{h}^{-1}\right)$ & 50000 & 50000 & 50000 \\
\hline & Revenue and Profit & & & \\
\hline
\end{tabular}

\begin{tabular}{|c|c|c|c|c|}
\hline \multirow[t]{2}{*}{ No } & \multirow[t]{2}{*}{ Output, input, and price } & \multicolumn{2}{|c|}{ Varietas } & \multirow{2}{*}{$\begin{array}{l}\text { Cihe } \\
\text { rang }\end{array}$} \\
\hline & & Sintanur & $\begin{array}{l}\text { Mentik } \\
\text { susu }\end{array}$ & \\
\hline 8 & $\begin{array}{l}\text { Raw material Input (IDR . } \\
{ }^{-1} \text { ) }\end{array}$ & 6000 & 6500 & 3800 \\
\hline 9 & Other Inputs (IDR $\cdot \mathrm{kg}^{-1}$ ) & 800 & 900 & 400 \\
\hline 10 & Production (IDR $\cdot \mathrm{kg}^{-1}$ ) & 8,000 & 10,312 & 4875 \\
\hline 11 & Added value (IDR $\cdot \mathrm{kg}^{-1}$ ) & 1,200 & 2,912 & $\begin{array}{r}675 . \\
0\end{array}$ \\
\hline 12 & Added value ratio AV (\%) & 0.15 & 0.28 & 0.14 \\
\hline 13 & $\begin{array}{l}\text { Revenue of Workers (IDR } \\
-1 \text { ) }\end{array}$ & 694.44 & 718.75 & $\begin{array}{r}354 . \\
17\end{array}$ \\
\hline 14 & Workers share of VA (\%) & 0.58 & 0.25 & 0.52 \\
\hline 15 & Profit (IDR $\cdot \mathrm{kg}^{-1}$ ) & 505 & 2,193 & $\begin{array}{r}320 . \\
8\end{array}$ \\
\hline 16 & Rate of Profit (\%) & 0.42 & 0.75 & 0.48 \\
\hline
\end{tabular}

The results of added value calculation by Hayami method in Table 2 showed that the average production organic on capability for one times harvest period on 0.25 hectares was $1,800 \mathrm{~kg}$ of harvested dry grain for farmer groups Sri Lestari (Sintanur) and $1,600 \mathrm{~kg}$ of harvested dry grain for farmer group of Mitra Organik (Mentik susu). While for inorganic rice (Ciherang), higher yields are obtained, which is equal to $2,400 \mathrm{~kg}$ of harvested dry grain. The average yield of organic rice (Sintanur and Mentik susu) was $1,200 \mathrm{~kg}, 1100 \mathrm{~kg}$ and an inorganic rice was $1,560 \mathrm{~kg}$. Labor was used to post-harvest activities, drying, grinding, sorting, and packaging, in the form of working day (HOK) units. Input of labor for organic rice (Sintanur and Mentik susu), and inorganic rice (Ciherang) is $25 \mathrm{HOK}, 23 \mathrm{HOK}$, and $17 \mathrm{HOK}$. Organic rice (Sintanur) uses more labor input than organic rice (Mentik Susu). This is because the farmer produced a lot of yellow and brown rice on Sintanur while milk white color is evenly distributed on Mentik susu. This is in accordance with the preliminary research by [7] that Mentik susu had white rice color compared to Sintanur. Furthermore, the biggest input of labor is during the drying process.

Sintanur required drying time of up to 4 days, while Mentik susu only need 3 days of drying. This is due to the characteristics of Mentik susu that is easily dry. When compared with Sintanur, the labor input of inorganic rice (Ciherang) was smaller. This is because of sorting activities was not carried out and product packaging only uses burlap sacks. Three types of rice products have labor efeciency0.01. That is, every rice processing required as many as 0.01 HOK labor. The use of labor does not make a difference in the use of labor even though the types of seeds used are different. Salary given by the two farmer groups are the same, an average of IDR 50,000 / HOK. 
Based on the calculation of Hayami's added value method, the conversion value for Sintanur, Mentik susu, ad inorganic rice (Ciherang) were 0.670 .69 , and 0.65. This means that everyone kilogram of harvested dry grain produced $0.67,0.69$, and $0,65 \mathrm{~kg}$ of rice of organic rice (sintanur and Mentik susu) and inorganic rice (Ciherang). Differences of conversion value between organic and inorganic rice occur because of different on post-harvest handling processes, grinding machines, and number of damaged products.

The price of harvested dry grain is obtained from the value of cost of production (CoP) which is total cost of rice farming. The result of previous study regarding the efficiency of organic rice farming carried out by [5] showed price of Rp. 6,500 / kg for Mentik susu, Rp. 6,000 / kg for Sintanur, and Rp. 3,800 / kg for inorganic rice (Ciherang). The price of other ingredients for Mentik susu is larger, namely Rp. $900 / \mathrm{kg}$ compared to the Rp. 800 / $\mathrm{kg}$ for Sintanur and Rp. 400 / kg for inorganic (Ciherang). This is because the packaging costs for Mentik susu and Sintanur used HDPP plastic packaging, while inorganic rice (Ciherng) used ordinary sacks.

The selling price of organic rice was different with inorganic rice (Ciherang), and Mentik susu was different with Sintanur. Selling price of Sintanur, Mentik susu, and inorganic rice (Ciherang), IDR 12,000/kg, IDR 15,000/kg, and IDR 7,500, respectively. The difference in selling prices of organic rice is caused by differences in seed varieties used, consumer preferences, and product marketing channels. Farmer groups of Sri Lestari used Sintanur seeds and sell the products to traders (not using their own trademarks) while farmer group of MitraOrganik using Mentik susu seeds and sell products with their own packaging and sell to wholesalers/shops. Mentik susu rice tends to be more fullffier and fragrant than Sintanur.

Mentik susu produced gets the highest added value compared to Sintanur and inorganic rice (Ciherang). Added values Mentik susu, Sintanur, and inorganic rice (Ciherang) were IDR 2,912.50, IDR 1,200 and IDR 675. The ratio of added value every rice varieties are different. The ratio of added value of Mentik susu was $28 \%$ and the ratio of value added of organic rice was $14 \%$. Based on the ratio of added value, the organic rice business provides added value because the ratio of value added produced meets the requirements of $>0$. This means that the organic rice business from every farmer group provides added value. The highest added value is in Mentik susu.

The profit of processing organic rice for one kilogram of harvested dry grain was vary between Rp. 320.8, - Rp. $2,193.75,-$. The biggest profit is obtained from Mentik susu of Rp. 2,193.75 with a share of profits of around $75 \%$. The lowest profit is for Sintanur of Rp. 505.56 with a share of $42 \%$ profit. Based on the added value analysis that has been done, it can be seen that organic rice business from the three types of products provides the biggest added value was Mentik susu. Research by [8] added value obtained for organic rice is higher than inorganic rice due to high selling prices. The results of the analysis explain that the type of seed used will provide higher added value and in accordance with the increase in income.
Organic rice processing should pay attention to the types of rice varieties, tastes / preferences of consumers, and product marketing channels. Integration of this can be able to increase added value and business profits. Income from organic rice that provides high profits is one of the determinants of business success. The role of the certification body is a very necessary factor to increase the selling value of organic rice with the value of the resulting rice making the organic rice business feasible to continue.

\section{CONCLUSION}

The results of the analysis showed that the organic rice of the Mentik susu gave higher added value compared to inorganic rice of the Sintanur 2,912 and 1,200 with an added value ratio of 0.28 and 0.15 , respectively. The value of profits obtained by organic rice Mentik susu and Sintanur is IDR 2,193.75 and 505.56 with a profit ratio of 0.75 and 0.42 , respectively. While inorganic rice had added value 675 with added value ratio 0.14 . The value of profits obtained by inorganic is IDR 320.8 with a profit ratio of 0.48 . This shows that organic rice Mentik susu provide more added value than Sintanur and inorganic rice (Ciherang).

\section{REFERENCES}

[1] Central Bureau of Statistics. 2018. National rice production data. BPS. Jakarta.

[2] Handayani S, Affandi MI, and Astuti S. 2018. Quality Analysis of Mentic Organic Rice Variety Milk and Sintanur Nutritional Approach. MATEC Web Conf. 215 02011, DOI: 10.1051/matecconf / 201821502011.

[3] Hu EA, Malik V, Sun Q. 2012. White rice consumption and risk of type 2 diabetes: metaanalysis and systematic review. BMJ. 344: e1454 doi: 10.1136 / bmj.e1454

[4] Handayani S and Affandi MI. 2019. Supply Chain Management Performance of Organic Rice in Pringsewu Regency. Journal of International Conference Proceedings. 2. AIBPM Publishing Group.

[5] Handayani S, Anggraini N, Yolandika C. 2019. Efficiency of Organic Padi Farming in Candipuro District. In Proceedings of the National Seminar on Agricultural Technology (Vol. 2018).

[6] Hayami, Y, Kawagui, T, Morooka, Y, Siregar, M. 1987. Agricultural Marketing and Processing in Upland Java a Perspective from a Sunda Village. CGPRT 8. The CGPRT Center. 
[7] Handayani S, Affandi MI, \& Susanti S. 2019. Analysis of Quality Characteristics of Organic Rice of MenthikSusu and Sintanur Varieties. Journal of Food System \& Agribusiness, 2 (2), 75-82.

[8] Nurmala D. 2012. Organic Rice Add Value and Margin ofRice Marketing Organic in Sumber Ngepoh Village, Lawang District, Malang Regency (Doctoral dissertation, Universitas Brawijaya). 